О.В. Рибалко та ін.] ; за ред. В. М. Кухаренка. Харків : Міськдрук, НТУ XПI, 2016. $-284 \mathrm{c}$.

8. Проскура С.Л. Формування професійної компетентності майбутніх бакалаврів комп'ютерних наук. Фізико-математична освіта. 2019. Випуск 2(20). С. 138-146. https://fmo-journal. fizmatsspu.sumy.ua/publ/4-1-0-522 (2019).

9. Положення про рейтингову систему оцінювання результатів навчання НТУУ «Київський політехнічний інститут ім. І.Сікорського» https://kpi.ua/regulations-RSO

10. Проскура С.Л Модель формування професійної компетентності майбутніх бакалаврів комп'ютерних наук Фізико-математична освіта. 2019. Випуск 3(21). С. 104-112.

11.Проскура С.Л Таксономія блума в оцінюванні результатів освітньої діяльності студентів. Звітна наукова конферениія Інституту інформачійних технологій $i$ засобів навчання НАПН України. 2020, м. Київ, Україна.

12. Турчин.А.И. Система контролю й й оцінювання навчальних досягнень студентів ВНЗ Німеччини. Наукові записки. Серія: Педагогіка. -2010 - № 1 .

DOI https://doi.org/10.30525/978-9934-588-80-8-2.67

\title{
ДО ПРОБЛЕМИ ОЦНЮВАННЯ УСПІШНОСТІ ЗДОБУВАЧІВ ВИЩОЇ ОСВІТИ В УМОВАХ ДИСТАНЦІЙНОГО НАВЧАННЯ
}

\author{
Ремньова А. Г. \\ кандидат педагогічних наук, \\ стариий викладач кафедри теорії та історії педагогіки \\ Начіональний педагогічний університет імені М. П. Драгоманова \\ м. Київ, Україна
}

Дистанційна форма навчання сьогодні є доволі відомою і поширеною у світовій практиці, особливо у освітньому просторі закладів вищої освіти. Це пояснюється змінами, що сталися наприкінці 20-го на початку 21-го століття у соціо-культурному, політичному та соціально-економічному житті багатьох країн світу: переходом до інформаційного суспільства, підвищенням рівня інформаційних технологій, глобалізацією, зміною освітньої парадигми (від концепції «освіта на все життя» до концепції «освіта впродовж всього життя»). 
Державна політика України щодо поширення дистанційного навчання знайшла своє відображення у багатьох документах: «Концепції розвитку дистанційної освіти в Україні» (2000), Наказ Міністерства освіти та науки України № 466 «Про затвердження Положення про дистанційне навчання» (2013), Законах України «Про освіту» (2017) та «Про повну загальну середню освіту» (2020).

Справжнім викликом на перевірку ефективності дистанційної форми навчання виявився карантин у зв'язку 3 пандемією коронавірусної інфекції, оголошений в Україні з 12 березня 2020 року. Раптовий перехід на дистанційну форму навчання всіх закладів освіти став вимушеним кроком, виявив чимало проблем у організації дистанційного навчання, разом 3 тим приніс чималий досвід, який можна проаналізувати та реалізувати у майбутньому.

Проблеми дистанційного навчання є об'єктом дослідження вітчизняних науковців ще з 1996 року. Різноманітні психолого-педагогічні аспекти дистанційного навчання розглядали у своїх працях Г. Балл, В. Биков, І. Булах, О. Григорьєва, Р. Гуревич, Ю. Дорошенко, М. Жалдак, В. Кремень, В. Луговий, Ю. Пасічник, Н. Сиротенко та інші.

Однією з важливих проблем дистанційного навчання у вищій школі під час карантину постала проблема контролю та оцінювання результатів навчальної діяльності студентів. Згідно Болонської системи студент, що навчається у ЗВО, має протягом усього семестру набирати рейтингові бали за відвідування, роботу на семінарських заняттях, за виконання індивідуальних навчально-дослідних завдань або творчих робіт, а також за модульний контроль, які наприкінці семестру підсумовують у загальний рейтинговий бал. Потім потрібно скласти іспит і студент отримує результат згідно семирівневої системи ECTS (максимум - 100 балів). Кожен викладач розробляє свою систему оцінювання відповідно до навчальної дисципліни, що викладає, подає їі у робочій програмі і доводить до відома студентів. Під час традиційного навчання студент отримує частину своїх рейтингових балів за усні види робіт: виступи на семінарах, участь у дискусіях, захист творчих робіт. Перехід на дистанційну форму навчання змусив багатьох викладачів переосмислити і перебудувати вже налаштовану систему оцінювання, як і всю систему роботи зі здобувачами вищої освіти.

Практика дистанційного навчання в Україні показала, що $\epsilon$ достатньо різноманітних форм і методів для контролю та оцінювання успішності студентів, які забезпечують всебічну, систематичну, повну, об'єктивну перевірку теоретичних знань, практичних умінь i компетентностей студентів. Отже, викладачам в умовах карантину необхідно було швидко ознайомитися і опанувати дистанційні методи 
оцінювання, а головне - вчасно організувати поточний, а потім i семестровий контроль. Згідно інформаційно-аналітичній довідці про результати опитування щодо стану використання технологій дистанційного навчання у закладах вищої освіти України, яке було проведене Державною службою якості освіти України у квітні-травні 2020 року, більшість викладачів та студентів, що брали участь у опитуванні, підтвердили здійснення поточного контролю. Найбільш популярним методом оцінювання під час поточного контролю успішності студентів став метод надсилання студентами виконаних завдань на електронну пошту викладачу [1]. Такий формат дозволив викладачам здійснити індивідуальний підхід до кожного студента під час перевірки завдань, хоча був найбільш затратним у часі, що привело до перевантаження викладачів під час дистанційної роботи.

Ефективним інструментом взаємодії між викладачем та студентом для поточного оцінювання та контролю якості знань стала дистанційна система навчання Moodle, яка дозволила не тільки вести спостереження за навчальною діяльністю студента, а й проводити автоматичну обробку результатів тестування, забезпечуючи швидкий зворотній зв'язок між студентом і навчальним матеріалом. Гнучкість системи організації тестування надала змогу проводити різні види контролю (у навчальному або контролюючому режимі) та використовувати різні типи завдань: запитання 3 альтернативним вибором або з множинним вибором зі списку відповідей, встановлення відповідностей або порядку послідовностей, завдання відкритого типу у формі есе, резюме, анотації, твору тощо. На жаль, результати опитування студентів та науково-педагогічних працівників показали, що лише 65,8 \% науковопедагогічних працівників використовували віртуальні освітні середовища, зокрема Moodle, для створення власного навчального контенту та організації забезпечення контролю за якістю навчання студентів (тести, анкети, електронний журнал) [1].

Найбільш оптимальними технологіями для такого виду контролю, як захист курсових та магістерських робіт, було визнано комунікаційні технології (Zoom, Skype, Google Meet), що забезпечували зворотній зв'язок i дозволяли ефективно здійснювати діалог між усіма учасниками процедури захисту. Фіксація процесу захисту курсових чи магістерських робіт сприяла запобіганню необ'єктивного оцінювання студентських робіт. Але викладачі та студенти зазначали, що доволі часто виникали технічні проблеми із забезпеченням таких комунікацій.

У червні 2020 року викладачів та студентів закладів вищої освіти України очікував ще один виклик - семестровий контроль результатів навчання здобувачів освіти. Згідно Листа МОН № 1/9-249 від 256 
14.05.20 року «Щодо організації поточного, семестрового контролю та атестації здобувачів освіти із застосуванням дистанційних технологій» заклади вищої освіти отримали методичну підтримку з питань організації оцінювання результатів навчання студентів, що дозволило максимально розширити можливості оцінювання їх успішності під час семестрового контролю за рахунок урізноманітнення інтернеттехнологій та засобів телефонного зв'язку [3].

Досвід дистанційного навчання в закладах вищої освіти в умовах карантину переконав всіх учасників освітнього процесу, що у сучасному світі традиційне навчання без дистанційної складової вже неможливе. Традиційне та дистанційне навчання має багато спільного - цілі, навчальні програми, методи викладання та систему оцінювання. Поєднання традиційного та дистанційного навчання дозволяє розширити освітні можливості студентів за рахунок гнучкості, врахування індивідуальних особливостей та освітніх потреб студентів, темпу та ритму засвоєння навчального матеріалу [2, с. 31], підвищення мотивації та самоорганізації здобувачів вищої освіти, здійснення взаємодії між учасниками освітнього процесу завдяки синхронній або асинхронній комунікації.

Разом 3 тим, використання дистанційних технологій у період карантину в закладах вищої освіти України виявило багато проблем: відсутність єдиної спільної системи онлайн-навчання, недостатня психологічна готовність викладачів та студентів до дистанційного навчання, цифровий розрив між викладачами та здобувачами вищої освіти, збільшення методичного навантаження на викладачів, підвищення кваліфікації педагогічних працівників, ідентифікація онлайн-студента, контроль за дотриманням студентами академічної доброчесності під час виконання творчих та індивідуальних завдань, недостатній рівень самоорганізації у здобувачів вищої освіти, що безпосередньо вплинуло і на проблему оцінювання успішності та контролю навчальної діяльності студентів.

У закладах вищої освіти, які ще до карантину мали досвід використання технологій дистанційного навчання, організація поточного оцінювання та семестрового контролю не викликала труднощів ні у студентів, ні у викладачів. Та запитань залишилося багато. Чи варто змінювати систему оцінювання успішності студентів в умовах змішаного або дистанційного навчання? Яким чином перебудувати систему оцінювання, щоб підвищити ефективність поточного та семестрового контролю якості знань здобувачів вищої освіти? Як заощадити час викладачам та студентам під час оцінювання та контролю навчальних досягнень в умовах дистанційного навчання? Ці та інші аспекти 
проблеми оцінювання успішності здобувачів вищої освіти в умовах дистанційного навчання потребують подальшого дослідження.

\section{Література:}

1. Інформаційно-аналітична довідка про результати опитування щодо стану використання технологій дистанційного навчання у закладах вищої освіти України. URL: http:/www.sqe.gov.ua/images/ materials/опитування/зво/Опитування_дистанційне\%20навчання_3ВО.p df (дата звернення: 23.09.2020).

2. Підготовка сучасного вчителя : інформаційно-технологічне забезпечення: монографія / За ред. О.І. Огієнка. Кіровоград : ІмексЛТД, 2013. 224 с.

3. Щодо організації поточного, семестрового контролю та атестації здобувачів освіти із застосуванням дистанційних технологій : Лист MOH України № 1/9-249 від 14.05.20 року. URL: http://osvita.ua/ legislation/Vishya_osvita/73574/ (дата звернення: 22.09.2020). 